\title{
Local Government Strategy and Foreign Direct Investment (FDI) level: Case Studies of Sleman and Kulon Progo district, Yogyakarta Special Region (DIY)
}

\author{
Miptahul Janah ${ }^{1}$, Dyah Mutiarin ${ }^{1}$ \\ \{dyahmutiarin@umy.ac.id² $\left.{ }^{2}\right\}$ \\ Universitas Muhammadiyah Yogyakarta ${ }^{1}$
}

\begin{abstract}
The research objective was to determine the extent to which local government strategy influences FDI level in Sleman and KulonProgo districts. The research was a qualitative one that used data and information that were obtained from government documents, macroeconomic indicators from local government statistics offices, interviews with relevant officials responsible and knowledgeable about investment in general and FDI in particular. Research findings found no evidence of local government strategy that was specifically tailored toward attracting FDI to the respective district. However, there is abundant evidence that determinants of FDI are in line with previous research results and theory. The results show that the key factors that have influenced a greater number of FDI to locate more of their production facilities in Sleman than in Kulon Progo include accessibility, availability of skilled manpower, good infrastructure, a responsive investment regulatory regime, quality information on investment potential, active involvement of the district government in showcasing investment potential through local, national and international fora. The existence of agglomeration effects in Sleman district has also played an important role, if not the most important, in making Sleman more attractive as FDI destination than Kulon Progo district.
\end{abstract}

Keywords: local government strategy, Foreign Direct Investment, agglomeration effects

\section{Introduction}

Investment is one of the drivers of economic growth in a region. FDI [1] is influenced negatively by inflation, while Benhabib and Spiegel [2] found interest to have negative impact on FDI. Seyoum and Manyak studied the relationship between private and public transparency and FDI. Using a sample of 58 developing countries, they concluded that transparency in both the private and public sector has a positive and significant influence on inward FDI flows to developing countries [3]. Moreover, higher private-sector transparency was found to have an even larger influence on FDI. Nonetheless, some previous research on FDI found transparency in the public sector to have larger influence on FDI than that in the private sector. Drabek and Payne for instance found that a country that increases its transparency in policies and institutions enjoys an increase in FDI [4]. Factors attributable for higher FDI in a highly transparent regime include reduced additional cost incurred for non- 
transparency; higher rate of cross-border mergers and acquisitions; stronger protection of property rights; and positive impact transparency has on business attitudes; and stronger and credible monitoring by external parties to the organisation.

The data on investment in DIY, has shown the investment realization and growth of PMA/PMDN in DIY in 2008 up to semester 1/2012, as presented in the table below:

Table 1. Investment Realizations and Growth of PMA/PMDN DIY, 2008-2012

Source: Regional Investment and Cooperation Board of DIY (BKPM DIY, 2013)

\begin{tabular}{ccccccc}
\hline & & & & PMDN+PMA & Growth & \\
No. & Year & PMDN $(\mathrm{Rp})$ & PMA $(\mathrm{Rp})$ & $\begin{array}{c}\text { (Rp) } \\
(\mathrm{Rp})\end{array}$ & Growth (\%) \\
\hline & & & 2.415 .461 .7 & 4.221 .888 .200 & 142.187 .9 & \\
1. & 2008 & 1.806 .426 .455 .845 & 44.857 & .702 & 60.933 & 3,49 \\
& & & 2.508 .131 .1 & 4.390 .645 .700 & 168.757 .5 & \\
2. & 2009 & 1.882 .514 .536 .845 & 63.857 & .702 & 00.000 & 3,99 \\
& & & 2.696 .046 .9 & 4.580 .972 .827 & 190.327 .1 & \\
3. & 2010 & \multirow{2}{*}{1.884 .923 .869 .797} & 57.447 & .244 & 26.542 & 4,33 \\
& & & 4.110 .436 .3 & 6.423 .578 .020 & 1.842 .605$. & \\
4. & 2011 & 2.313 .141 .695 .784 & 24.224 & .008 & 192.764 & 40,22 \\
& & & $4,250,121,5$ & $7,056,066,141$ & $632,488,1$ & \\
5. & 2012 & $2,805,944,605,930$ & 35,829 &, 759 & 21,751 & 9,85 \\
\hline
\end{tabular}

From the zoning aspect, the investment realization of DIY in 2012 still centralized in Sleman Regency and Yogyakarta City. The amount of $91,68 \%$ of the total investment realization of DIY in 2012 was located in Sleman and Yogyakarta city while GunungKidul and KulonProgo Regency are only hold $2,4 \%$ of the total.

\begin{tabular}{clcc}
\hline No. & Regency/city & \multicolumn{2}{c}{ The investment Realization up to 2012 } \\
& & $\begin{array}{c}\text { PMDN (Domestic Direct } \\
\text { Investment) }\end{array}$ & PMA (Foreign Direct Investment) \\
\hline 1. & Yogyakarta City & $1,303,134,160,910$ & $1,648,551,898,790$ \\
2. & Sleman & $1,242,033,289,418$ & $2,276,146,234,364$ \\
3. & Bantul & $191,257,086,711$ & $226,005,372,675$ \\
4. & KulonProgo & $34,017,508,942$ & $3,078,450,000$ \\
5. & GunungKidul & $35,502,559,948$ & $96,339,580,000$ \\
Total & & $2,805,944,605,929$ & $4,250,121,535,829$ \\
\hline
\end{tabular}

Source: Regional Investment and Cooperation Board of DIY (BKPM DIY, 2013)

On the other side, the investment portrayed that there was an agglomeration economy occur due to the fact that certain locations have the key factors of production that investors need at a lower cost than in other locations. Such factors include the availability of sufficient technology, capital, and infrastructure. However, not all areas of regions have the same potential to attract investment or FDI. This is because some areas may not have the resource seeking, marketing seeking, efficiency-seeking, and strategic importance that investors need to establish their firms in a certain area. To that end, those locations that already have a large number of firms have a high likelihood of attracting new investments, thereby generating even larger agglomeration economies that will continue to attract future investment to such locations [5]. This is why the existence of agglomeration economies in urban areas has been blamed for increasing income disparity between rural and urban areas.

To that end, improving the distribution of investment realization among regencies, which should help in reducing regional development disparity, has been identified by BKPM DIY as 
an important component in promoting regional economic development, poverty and income inequality reduction, and fairness. The goal general goal of this research is to determine the extent to which local government strategy influence FDI level in Sleman and KulonProgo district.

\section{Method}

The research design for this paper is descriptive in nature. The research used primary and secondary data which were obtained using interviews, direct observation in the field, reading official documents and reports, deciphering the trend in data on FDI by sector, location and investors in statistics reports. To that end, data sources included local government statistics offices, national bureau for statistics, information obtained from officials with knowledge on investments in general and FDI in particular in the Sleman and KulonProgo district government. Meanwhile, to analyze the data, the research employed descriptive analysis techniques that evaluated data and information to determine emerging patterns and themes. The themes that emerged served as guidance and inference to draw conclusions, which were tailored toward finding answers to the research question. The data analysis technic used by the author is data reduction, summarizing and verification based on accurate information. The author made some comparisons of the phenomenon in both regencies (Sleman and KulonProgo) regarding the object of the study of government strategy on attracting FDI and agglomeration economies leverage toward investment and economic growth in Sleman and KulonProgo Regency.

Table 3. Investment Opportunities and Market Segment

\begin{tabular}{|c|c|c|c|c|}
\hline \multirow[t]{2}{*}{ No. } & \multicolumn{2}{|c|}{ Investment Opportunities } & \multicolumn{2}{|c|}{ Market Segment } \\
\hline & $\begin{array}{l}\text { Sleman } \\
\text { District }\end{array}$ & $\begin{array}{l}\text { KulonProgo } \\
\text { District }\end{array}$ & Sleman district & KulonProgo District \\
\hline 1. & $\begin{array}{l}\text { Development of } \\
\text { Maguwoharjo Stadium }\end{array}$ & $\begin{array}{l}\text { Development of } \\
\text { TanjungAdikarto } \\
\text { Fishery Port }\end{array}$ & $\begin{array}{l}\text { Tourism, } \\
\text { Education }\end{array}$ & Industry \\
\hline 2. & $\begin{array}{l}\text { Development of } \\
\text { CandiGebang and } \\
\text { EmbungTambakboyo }\end{array}$ & $\begin{array}{l}\text { The Development of a } \\
\text { New International } \\
\text { Airport }\end{array}$ & Tourism & Trading, Tourism \\
\hline 3. & $\begin{array}{l}\text { Development of Mount } \\
\text { Merapi Museum } \\
\text { Region }\end{array}$ & $\begin{array}{l}\text { Pig Iron foundry } \\
\text { factory }\end{array}$ & Tourism & Mining, Industry \\
\hline 4. & $\begin{array}{l}\text { Development of Tourist } \\
\text { Objects }\end{array}$ & $\begin{array}{l}\text { The development of } \\
\text { South Java Road } \\
\text { Route }\end{array}$ & Tourism & $\begin{array}{l}\text { The development of } \\
\text { South Java Road } \\
\text { Route }\end{array}$ \\
\hline 5. & Student Dormitories & $\begin{array}{l}\text { The development of } \\
\text { Sentolo Industrial } \\
\text { Area }\end{array}$ & Education & $\begin{array}{l}\text { The development of } \\
\text { Sentolo Industrial } \\
\text { Area }\end{array}$ \\
\hline 6. & $\begin{array}{l}\text { Motorbike Assembling } \\
\text { Industry }\end{array}$ & Tourism Objects & Trading & Tourism \\
\hline 7. & $\begin{array}{l}\text { Computer Assembling } \\
\text { Industry }\end{array}$ & $\begin{array}{l}\text { Cacao, Herbal, and } \\
\text { Coconut Processing } \\
\text { Industry }\end{array}$ & $\begin{array}{l}\text { Trading, } \\
\text { Industry }\end{array}$ & Industry \\
\hline
\end{tabular}

Source: Investment Promotion Book 2013 [6]

\section{Result and Discussion}


Key FDI activities for each district are based on the major economic sectors that support the respective local economy. Key economic sectors for Sleman district economy include tourism, education, trading and services. To that end, the potential for FDI activities in Sleman are also related to the development of tourism, education sector, trading and supporting services. Meanwhile, Kulon Progo, which still relies heavily on the agricultural sector and natural resources, FDI main activities are in areas of infrastructure development, tourism, natural resource exploration, processing and exploitation, tourism, and mining extraction and processing industry. Specifically, potential FDI sectors and activities in Sleman district include the development of Maguwoharjo Stadium, Candi Gebang and Embung Tambak boyo, Mount Merapi Museum Region, Tourist Objects, student dormitories, motorbike assembling industry, and computer assembling industry, KulonProgo district offers potential activities for FDI investors in the development of Tanjung Adikarto Fishery Port, New International Airport, Pig Iron processing facilities, construction of South Java Road Route, Sentolo Industrial Area, tourism objects, and Cacao, Herbal, and Coconut Processing Industry. Thus, FDI potential activities in Sleman and Kulon Progo districts have some similarities in some aspects such as the role of developing tourism and trading, there are major differences in the key FDI sectors the two districts offer, which are attributable to the location, geography and importance of natural resource endowment in district development, availability of vacant and unused land, and level of economic and social development.

Research results did not find evidence that the two district government deliberately formulate and normatively, local investment is considered as one of the important power in accelerating economic growth and development of a region. After the implantation of local autonomy, the local government such being more concern toward the investment flows, the acceleration of economy and development were only possible if it's supported by the significant investment flows. That strong perception has pushed up the local government to build a good investment climate. Moreover, the local government also has to consider what aspects that may influence foreign direct investment determination.

Behrman (United Nations Economic and Social Commission for Asia and the Pacific \& ESCAP, 2017) was developed the typology to explain the different objectives of FDI:

\section{a. Resource Seeking FDI}

This type of FDI was particularly looking for the availability of raw material, low-skilled labour cost, labour skill, and other asset innovation, physical infrastructure, etc.

\section{b. Market seeking FDI}

Market seeking FDI was generally considering the market size and market growth of a region by analysis the income per capita or the economic growth whether a region has a good market structure or not that prospective for the development of their business.

\section{c. Efficiency Seeking FDI}

This type of FDI was mainly looking for the labour productivity and other input costs that might help minimizing the expenditure of the companies toward the labour cost, transportation and communication costs.

\section{d. Strategic Asset/Capabilities seeking FDI}


This type of FDI was particularly looking for a region that has established local firms, developed human capital with knowledge about markets, competitors and R\&D matters.

Sleman and KulonProgo Regency were able to attract or naturally pull up the FDI Companies with different objectives. Almost all types of FDI were investing in Sleman Regency. Meanwhile, it can be concluded that mainly the FDI companies, which investing in KulonProgo Regency were the Resource Seeking FDI. For instance, PT. JogjaMagasa Iron (JMI), the company that processes and produce pig iron explored in the south coast of KulonProgo. Presumably, it is impossible for them to invest in Sleman Regency or other regencies/city because the source of raw materials for their business was not available but in KulonProgo.

FDI companies in Sleman Regency generally were the market, efficiency and capabilities seeking FDI. By sectors, which industrial, and service and commerce are dominated, it may assumes that the FDI companies were seeking for a well market structure by considering Sleman Regency's role as the urban sprawl and population and economies agglomerations centre in DIY. The agglomeration economies theory explained the role of urbanization economies and localization economies are influencing the urbanization providence because the people and investors were more likely and prefer the urban area that offers the cost-efficiency, accessibility, and the urban infrastructures. The localization providence is rising because of the geographical proximity toward the raw materials source, labour, and knowledge spillover that promising the spatial benefits [6]. Other factors that have contributed to higher concentration of FDI in Slemandisttrcit than in KulonProgo, include high level of skilled manpower, better physical infrastructures, accessibility, a heterogeneous and friendly society as well as the large market as a result of the vast urban sprawl of DIY. On the contrary, KulonProgo district only offers low skilled labor, close proximity to future mega projects (International Airport and Modern Fishery Harbour) and its role as one of the locations that has been designated as a special industrial zone in DIY as stipulated in Government Regulation No. 24/ 2009 on industrial zone and Ministry Regulation No. 35/2010 on the establishment of industrial zones. Consequently, the district has laid the groundwork for developing the policy standards that will apply Sentolo Industrial Zone, which is designated as economic, industrial and investment centre.

FDI Companies in Sleman district can be regarded as driven by the need to achieve market, efficiency and capabilities seeking rather than resource seeking. This is attributable to the fact that Sleman district has limited natural resources, suffers from land shortage for expansion. On the other hand, KulonProgo district is rich in natural resources especially for agricultural and mining sectors. To that end, FDI that are located in the district are resource intensive as well as low skill labor demanding. The district does not have a strong market to pull FDI, because of its lower income per capita and lower educational attainment which contribute its low HDI in relation to Sleman district

As regards, the influence that agglomeration effects on the establishment of a larger number of FDI in Sleman district than in KulonProgo district, this is incontestable. The concentration of economic activities in Sleman district are mainly in the tertiary sector that include trade, hotels, and restaurant sectors, most of which are located in Depok sub district. Inevitably most FDI projects are located in Depok sub district as well. Meanwhile, KulonProgo district depends mainly on agriculture, which by nature does not generate agglomeration effects as is akin to the tertiary and industry sector. To that end, based on observation of the concentration of most of the FDI in DIY, which is Depok, Sleman district, the inference that can be drawn is that agglomeration effects have created conditions that made 
the district more attractive as an FDI location that KulonProgo, even with absence of other factors discussed in this paper.

As regards developing a strategy specifically to direct and influence FDI flows to the two districts, results were unable to establish conclusively that either Sleman or KulonProgo district or both had one in place as. Nonetheless, findings in this research corroborate results that were established in previous research by Orlando Gomes, Seyoum and Manyak on the general determinants of FDI such as resource, market, efficiency-seeking, size of the market, skilled manpower, accessibility among other factors [3]-[5]. Asieduon the positive relationship between an investment supportive climate that is characterized by transparency, accountability, predictability and legal certainty and FDI level.

\section{Conclusion}

The main objective of this research was to determine the extent to which local government strategy plays an important part in the location of FDI in Sleman and KulonProgo districts, DIY. Research findings did not find evidence of local government strategy that was specifically aimed at attracting FDI to the respective district. However, there is abundant evidence that the determinants of FDI are in line with previous research results and theory. The key factors that have influenced a greater number of FDI to locate more of their production facilities in Sleman than in KulonProgo include accessibility, availability of skilled manpower, good infrastructure, a responsive investment regulatory regime, quality information on investment potential. One good example is the act that investors in Sleman district do not find obstacles in processing working permits for foreign workers under their employment.

It must also be noted that Sleman district has a larger potential market than KulonProgo due to the former's higher economic and social development as attested by HDI, income per capita, and lower poverty incidence. KulonProgo has the highest poverty incidence in DIY province even nation level, while Slemandistict has one of the lowest poverty levels in the country. Sleman district has in place a well-planned, streamlined, investment planning and promotion strategy that is keen on widening its reach through local, national and international networking. KulonProgo, on the contrary, still lacks such a strategy. The existence of agglomeration effects in Sleman district has also played an a role, if not the most important, in making Sleman more attractive as FDI destination than Kulon Progo district.

\section{References}

[1] P. J. Buckley, L. J. Clegg, A. R. Cross, L. Xin, H. Voss, and Z. Ping, "The Determinants of Chinese Outward Foreign Direct Investment," J. Int. Bus. Stud., vol. 38, no. 4, pp. 499-518, 2007.

[2] J. Benhabib and M. Spiegel, "The Role of Financial Development in Growth and Investment," J. Econ. Growth, vol. 5, no. 4, pp. 341-360, 2000.

[3] B. Seyoum and T. G. Manyak, "The impact of public and private sector transparency on foreign direct investment in developing countries," Crit. Perspect. Int. Bus., vol. 5, no. 3, pp. 187-206, 2009.

[4] Z. Drabek and W. Payne, "The Impact of Transparency on Foreign Direct Investment,” J. Econ. Integr., vol. 17, pp. 777-810, 2002. 
[5] O. Gomes, Decentralized allocation of human capital and nonlinear growth. Germany: University Library of Munich, 2007.

[6] M. Kuncoro, "Ekonomi kaaglomerasi: dinamika dan dimensi spasial kluster industri Indonesia [Economics of agglomeration: dynamics and spatial dimension of Indonesia’s industrial clusters].” UPP STIM YKPN, Yogyakarta, 2012. 